\title{
PEMBUATAN APLIKASI PEMESANAN BANNER DI WARNA PRINT KOTA CIMAHI
}

\author{
Johni S Pasaribu \\ Teknik Informatika, Fakultas IT \\ Politeknik Piksi Ganesha \\ Jln Gatot Subroto 301 Bandung \\ johni_0106@yahoo.com
}

\begin{abstract}
Abstrak
Teknologi sekarang ini berkembang sangat cepat, tidak terkecuali teknologi informasi dan komunikasi. Untuk itu diperlukan langkah yang cepat dalam mengantisipasinya. Teknologi informasi dan komunikasi sudah memasuki dalam segala aspek kehidupan termasuk dunia bisnis. Hal ini disebabkan karena pengerjaan yang dibantu oleh teknologi informasi dapat meminimalkan kesalahan bahkan kerugian yang akan terjadi. Warna Print adalah perusahaan yang bergerak pada bidang percetakan, yaitu melayani desain banner dan cetak banner dan sedang menghadapi masalah di bidang pemesanannya. Sistem pemesanan banner yang dilakukan di Warna Print masih dilakukan secara konvensional. Misalnya pada pencatatan pemesanan, pembuatan faktur pemesanan hingga pengambilan pemesanan maupun laporan transaksi masih mengandalkan pencatatan di atas nota. Hal ini tentunya dapat menyebabkan kehilangan ataupun kerusakan data pemesanan maupun transaksi penjualan tersebut.
\end{abstract}

Dengan dirancangnya aplikasi ini akan dapat membantu memperlancar proses transaksi pada Warna Print. Perancangan aplikasi ini menggunakan Netbeans IDE dengan bahasa pemrograman Java dan program database MySQL. Aplikasi ini memiliki keamanan yang terjamin, karena hanya pemilik dan karyawan yang memiliki username serta password yang dapat mengakses aplikasi ini. Di samping itu tingkat kesalahan dalam melakukan pencatatan pemesanan sangat kecil, karena masing-masing pelanggan menerima nomor transaksi yang berbeda, sehingga dapat meminimalkan kesalahan pada laporan transaksi.

Kata kunci: Aplikasi, Pemesanan Banner, Orientasi Obyek, Prototipe

\begin{abstract}
Nowadays technology is developing very fast, including information and communication technology. For that we need fast steps in following it. Information and communication technology has entered all aspects of life, including the business world. This is because the work assisted by information technology can minimize errors and even losses that will occur. Warna Print is a company engaged in the printing sector, which serves banner designs and banner printing and is currently facing problems in the field of ordering. The banner ordering system used in Warna Print is still done conventionally. For example, in recording orders, making order invoices to taking orders and transaction reports, they still rely on recording on notes. This of course can cause loss or damage to the order data and sales transactions.

With the design of this application will be able to help expedite the transaction process on Color Print. The design of this application uses the Netbeans IDE with the Java programming language and the MYSQL database program. This application has guaranteed security, because only owners and employees who have a username and password can access this application. In addition, the error rate in recording orders is very small, because each customer receives a different transaction number, so as to minimize errors on the transaction report.
\end{abstract}

Keywords: Application, Banner Ordering, Object Oriented, Prototype 


\section{Pendahuluan}

Warna Print adalah perusahaan yang bergerak di bidang percetakan yaitu melayani desain banner dan cetak banner. Warna Print beralamat di Jl. Gatot Subroto No.68, Karangmekar, Kec. Cimahi Tengah, Kota Cimahi, Jawa Barat 40523. Dalam menjalankan usahanya, Warna Print masih memberlakukan proses pengolahan data pemesanan banner secara manual. Adapun prosesnya yaitu pelanggan memesan banner dan melakukan pembayaran baik lunas maupun hanya $50 \%$. Kemudian kasir mencatat pemesanan dan memberikan masing-masing satu bukti pemesanan dan pembayaran untuk pelanggan dan masing-masing satu bukti lainnya disimpan. Seringkali bukti pemesanan tersebut hilang baik pada pelanggan maupun pihak Warna Print. Setelah adanya pesanan, pihak Warna Print akan membuat pesanan. Setelah barang selesai maka pelanggan akan mengambil barang dengan memberikan bukti pemesanan. Kasir mencatat pengambilan dan memberikan satu bukti pengambilan barang dan satu bukti untuk disimpan. Disini juga bukti transaksi pembayaran tersebut bisa hilang di kantor tersebut. Oleh karena itu, pengolahan data pada Warna Print yang dilakukan secara manual seringkali mengakibatkan terjadi kesalahan dan kesulitan dalam pencarian data pemesanan banner dan pembuatan laporan transaksi pembayaran, terutama pada bagian kasir.

Dari permasalahan yang dihadapi oleh Warna Print dapat disimpulkan bahwa perusahaan tersebut membutuhkan sebuah aplikasi pemesanan banner yang bisa menampung produk-produk yang ada dalam perusahaan tersebut, sehingga memberikan kemudahan kepada konsumen dalam mendapatkan informasi maupun dalam membeli produk banner yang dijual oleh perusahaan tersebut. Pelanggan juga akan tidak merasa terbuang waktunya dalam mencari informasi barang yang diinginkannya dan juga pelanggan tidak akan beralih ke toko lain. Selain itu perusahaan juga tidak akan melakukan kesalahan pencatatan dan perhitungan atas transaksi yang terjadi maupun pembuatan laporan transaksi pemesanan banner.

Dengan demikian ada beberapa hal yang menjadi permasalahan pada Warna Print karena pengolahan data secara manual yaitu:

1. Penyimpanan data yang kurang efektif, karena data transaksi, data pengadaan dan pemakaian disimpan dalam bentuk catatan kertas sehingga dapat terjadi kemungkinan hilang atau rusak.

2. Terjadinya kesalahan pencatatan dan perhitungan atas transaksi yang terjadi maupun pembuatan laporan.

Adapun tujuan penelitian yang ingin dicapai sebagai berikut:

1. Memudahkan dalam pencatatan dan pengelolaan data sehingga dapat meningkatkan efisiensi waktu

2. Dihasilkannya basis data pada aplikasi pemesanan banner sehingga waktu dan tenaga yang dibutuhkan petugas dalam melayani pelanggan lebih efektif dan efisien

3. Memudahkan kasir Warna Print dalam melakukan pembuatan laporan yang tepat guna pada aplikasi pemesanan banner yang tersimpan dalam basis data MySQL

Adapun ruang lingkup dari aplikasi pemesanan banner pada Warna Print ini meliputi pembatasan hak akses penggunaan aplikasi, penyimpanan data pemesanan dan pembayaran, penyimpanan data pengambilan dan pelunasan, laporan transaksi penjualan banner, Database management system menggunakan MySQL dan bahasa pemrograman menggunakan Java. Manfaat dari aplikasi pemesanan banner pada Warna Print ini adalah memudahkan admin dalam pengelolaan data pelanggan, pemesanan banner, pengambilan banner pelanggan, kelola laporan dan backup restore data. Manfaat lainnya yaitu memudahkan kasir dalam pemesanan banner pelanggan, pengambilan banner pelanggan dan kelola laporan.

\section{LANDASAN TEORI}

\section{II.1 Aplikasi}

Aplikasi adalah adalah program siap pakai yang dibuat oleh suatu perusahaan komputer untuk mengerjakan tugas-tugas tertentu, misalnya Microsoft Word, Microsoft Excel, Microsoft Access, dan sebagainya (Dhanta, 2009). Menurut Abdul Kadir, aplikasi adalah program siap pakai yang dapat digunakan untuk menjalankan perintah-perintah dari pengguna aplikasi tersebut dengan tujuan mendapatkan hasil yang lebih akurat sesuai dengan tujuan pembuatan aplikasi tersebut (Kadir, 2003). Penulis Abdul Kadir mengatakan dalam buku yang lain, program aplikasi adalah program yang dibuat 
oleh pemakai yang ditujukan untuk melakukan suatu tugas khusus bagi pengguna atau aplikasi yang lain. Aplikasi juga diartikan sebagai penggunaan atau penerapan suatu konsep yang menjadi pokok pembahasan atau sebagai program komputer yang dibuat untuk menolong manusia dalam melaksanakan tugas tertentu. Aplikasi software yang dirancang untuk penggunaan tugas khusus, klasifikasi luas ini dapat dibagi menjadi dua bagian yaitu (Kadir, 2008):

a. system software yaitu perangkat lunak yang digunakan untuk membantu menjalankan perangkat keras dan sistem komputer. Termasuk dalam kelompok ini adalah sistem operasi, driver perangkat keras, perangkat lunak pendiagnosa, windowing system, utilities dan lain-lain. Dari kelompok ini sistem operasi merupakan perangkat lunak yang paling penting. Contohnya: Microsoft Windows, Apple Mac OS , Linux, Android, dan sebagainya.

b. aplikasi paket yaitu sebuah program komputer yang digunakan untuk menjalankan suatu perintah user yang dirancang untuk jenis tugas tertentu, contohnya: produk-produk Microsoft (Office, Excel, Word, PowerPoint, Outlook, dsb), edit gambar (Corel Draw, Adobe Photoshop, Picasa), Internet browsers (Firefox, Safari, Chrome), antivirus (Avira, Smadav, Avast), dan sebagainya.

Dari kedua pengertian di atas dapat disimpulkan bahwa aplikasi adalah sekumpulan perintah atau kode yang disusun secara sistematik untuk menjalankan suatu perintah yang diberikan oleh manusia melalui komponen atau hardware komputer yang digunakan dalam menjalankan program aplikasi sehingga bisa membantu manusia untuk memberikan solusi dari apa yang diinginkan.

Menurut Kamus Besar Bahasa Indonesia (KBBI) aplikasi adalah program komputer atau perangkat lunak yang didesain untuk mengerjakan tugas tertentu. Secara umum pengertian aplikasi adalah suatu program yang siap untuk digunakan untuk melaksanakan misi tertentu bagi pengguna jasa aplikasi serta dikaitkan penggunaan aplikasi lain untuk sasaran yang akan dituju. Menurut kamus komputer eksekutif, aplikasi mempunyai arti yaitu pemecahan masalah yang menggunakan salah satu teknik pemrosesan data yang biasanya berpacu pada sebuah komputansi maupun pemrosesan data yang diharapkan (Juansyah, 2015)

\section{II.2 Pemesanan}

Istilah pemesanan disini adalah banyaknya jumlah pemesanan jasa untuk dikerjakan di dalam periode waktu tertentu. Berikut ini adalah pengertian pemesanan menurut masing-masing para ahli di bidangnya tertentu. Menurut Edwin dan Chris, pemesanan dalam arti umum adalah perjanjian pemesanan (booking) antara dua pihak atau lebih. Perjanjian pemesanan tersebut dapat berupa perjanjian atas pemesanan suatu barang, ruangan, kamar, tempat duduk dan lainnya pada waktu tertentu dan disertai dengan produk jasanya. Produk jasa yang dimaksud adalah jasa yang ditawarkan pada perjanjian pemesanan tempat tersebut, seperti pada perusahaan penerbangan atau perusahaan transportasi lainnya adalah perpindahan manusia atau benda dari satu tempat ke tempat lainnya (Chris, 1999).

Menurut Gouzali Saydam, pemesanan adalah penerimaan pesanan (booking) dari pelanggan terhadap suatu produk yang ada. Lanjutan dari pemesanan tadi adalah pengiriman produk agar sampai ke tangan pemesan (pelanggan) dengan baik (Saydam, 1996). Menurut Agus, pemesanan adalah keseluruhan proses kegiatan yang berkaitan dengan pengelolaan inventory atau persediaan tempat pendistribusian produk dan catatan keseluruhan transaksi pemesanan tempat baik untuk penumpang maupun barang (cargo) (Ahyari, 1999).

Berdasarkan definisi-definisi pemesanan di atas tadi, maka kesimpulan dari pemesanan adalah suatu perjanjian pemesanan yang dilakukan oleh dua pihak atau lebih yaitu pemberi dan pemakai jasa dan atau barang untuk memenuhi kebutuhannya sehingga dapat digunakan. Perjanjian pemesanan tersebut dapat berupa atas pemesanan barang, ruangan, tempat duduk, kamar dan lainnya pada periode waktu tertentu.

\section{II.3 XAMPP}

XAMPP adalah software web server Apache yang di dalamnya sudah tersedia database server MySQL dan support PHP Programming. Jadi XAMPP merupakan paket installasi Apache, PHP dan MySQL instant yang dapat digunakan untuk membantu proses installasi ketiga produk tersebut (Aditya, 2011). XAMPP merupakan software yang mudah digunakan, gratis dan mendukung instalasi di
Johni S Pasaribu

Jurnal Ilmiah Teknologi Informasi Terapan

Volume 7, No 2, 15 April 2021 
Linux dan Windows. Keuntungan lainnya adalah cuma menginstal satu kali sudah tersedia Apache Web Server, MySQL Database Server, PHP Support (PHP 4 dan PHP 5) dan beberapa modul lainnya. XAMPP merupakan paket PHP dan MySQL berbasis open source, yang dapat digunakan sebagai tool pembantu pengembangan aplikasi berbasis PHP. XAMPP mengombinasikan beberapa paket perangkat lunak berbeda ke dalam satu paket (Riyanto, 2010).

\section{II.4 UML}

Menurut Adi Nugroho bahwa UML (Unified Modeling Language) adalah bahasa pemodelan untuk sistem atau perangkat lunak yang berparadigma (berorientasi objek). Pemodelan (modeling) sesungguhnya digunakan untuk penyederhanaan permasalahan permasalahan yang kompleks sedemikian rupa sehingga lebih mudah dipelajari dan dipahami (Nugroho, 2005).

\section{II.5 Relational Unified Process (RUP)}

Metode penelitian yang digunakan dalam penelitian ini adalah metode Penelitian dan Pengembangan (Research and Development, $R \& D$ ). R\&D merupakan metode penelitian yang digunakan untuk menghasilkan produk hingga menguji keefektifan produk tersebut (Sugiyono, 2014). Dalam melakukan pengembangan perangkat lunak, peneliti mengunakan proses Relational Unified Process (RUP). Proses pengulangan/iteratif pada RUP secara global dapat dlihat sebagai berikut:

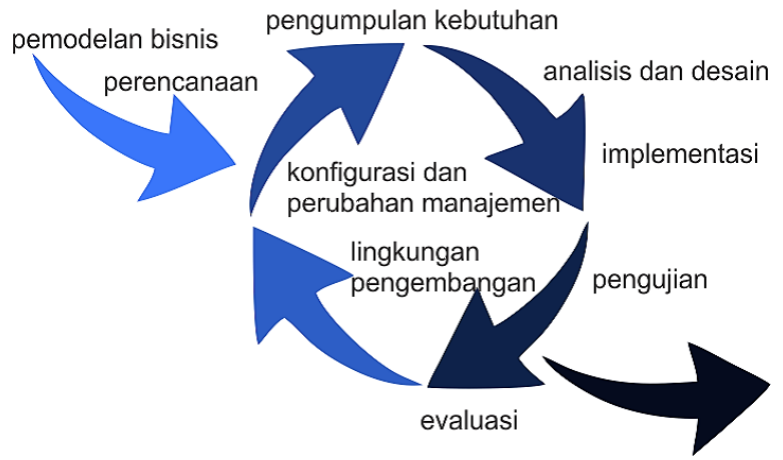

Gambar I. Proses iteratif RUP

Proses RUP ini adalah pendekatan yang berulang-ulang (iterative), fokus pada arsitektur (architecture-centric), lebih diarahkan berdasarkan penggunaan kasus (use case driven). Proses RUP ini merupakan proses dengan pendefinisian yang lebih baik (well defined) dan penstrukturan yang baik (well structured). Proses RUP ini menggunakan pendekatan sistematik dan sekuensial untuk tingkat kemajuan system mulai pada tahap analisis, desain, kode, pengujian, dan pemeliharaan (Pressman, 2012). Peneliti menggabungkan proses RUP dengan paradigma prototyping untuk membantu dalam mendefinisikan kebutuhan pengguna dan mengantisipasi perubahan kebutuhan dalam proses pengembangan perangkat lunak (Munnasar, N.M.A and Govardhan, 2010). Prototyping adalah teknik yang dapat diimplementasikan ke dalam konteks model proses lain, meskipun paradigma prototyping dapat digunakan sebagai proses model yang berdiri sendiri (Pressman, 2012). Paradigma prototyping dapat membantu pengembang dan pengguna dalam memahami apa yang harus dibangun ketika persyaratan masih bersifat umum. Menurut Menurut A.S Rosa dan M. Shalahudin, RUP memiliki 4 tahap atau fase yang dapat dilakukan pula secara iteratif. Berikut adalah penjelasan untuk setiap fase RUP (Shalahuddin, M \& Rossa, 2013), (Pressman, 2012) adalah sebagai berikut:

1. Inception (permulaan). Tahap ini lebih pada memodelkan proses bisnis yang dibutuhkan (business modeling) dan mendefinisikan kebutuhan akan sistem yang akan dibuat (requirements). Peneliti melakukan analisis kebutuhan yang berupa studi lapangan (observasi), wawancara, dan pencarian penelitian yang relevan (literatur). Hasil yang didapat adalah berupa user requirement atau data yang berhubungan dengan keinginan pengguna dan software requirement (kebutuhan perangkat lunak).

2. Elaboration (perluasaan/perencanaan). Tahap ini lebih difokuskan pada perencanaan arsitektur sistem. Tahap ini juga dapat mendeteksi apakah arsitektur sistem yang diinginkan dapat dibuat atau tidak. Mendeteksi resiko yang mungkin terjadi dari arsitektur yang dibuat. Tahap ini lebih pada analisis dan desain sistem serta implementasi sistem pada purwarupa sistem (prototype). Tahapan system and software design ini adalah proses multi langkah yang berfokus pada empat atribut sebuah program yang berbeda: struktur data, arsitektur perangkat lunak, representasi interface, dan detail (algoritma) prosedural. Tahapan ini menghasilkan system requirement. 
3. Construction (konstruksi). Tahap ini fokus pada pengembangan komponen dan fiturfitur sistem. Tahapan ini lebih pada implementasi dan pengujian sistem yang fokus pada implementasi perangkat lunak pada kode program. Tahap system and software design yang sudah diselesaikan kemudian dilanjutkan ke tahap penerjemahan bahasa ke dalam kode-kode dengan menggunakan bahasa pemrograman tertentu yang dapat dimengerti oleh komputer. Program yang dibangun langsung diuji eksternal untuk mengetahui kesalahankesalahan yang terjadi dan memastikan bahwa input yang diberikan pada sistem mampu memberikan output yang aktual dan sesuai yang diinginkan pengguna. Tahap ini menghasilkan produk perangkat lunak dimana menjadi syarat dari Initial Operational Capability Milestone atau batas/tonggak kemampuan operasional awal.

4. Transition (transisi). Tahap ini lebih pada deployment atau instalasi sistem agar dapat dimengerti oleh user. Tahap ini menghasilkan produk perangkat lunak dimana menjadi syarat dari Initial Operational Capability Milestone atau batas/tonggak kemampuan operasional awal. Mengoperasikan program dilingkungannya dan melakukan pemeliharaan, seperti penyesuaian atau perubahan karena adaptasi dengan situasi sebenarnya. Aktifitas pada tahap ini termasuk pada pelatihan user, pemeliharaan dan pengujian sistem apakah sudah memenuhi harapan user.

Adapun metode pengumpulan data dengan melakukan observasi untuk mengamati secara langsung sistem yang berjalan serta melakukan wawancara sehingga memudahkan dalam mendapatkan informasi dan kebutuhan sistem yang akan dibangun.

\section{Perancangan Dan IMPLEMEnTaSI}

Seperti telah dibahas sebelumnya, peneliti menggunakan proses Relational Unified Process (RUP) yaitu: pemodelan bisnis, pengumpulan kebutuhan, analisis dan desain, implementasi dan pengujian.

\section{III.1 Pengumpulan Kebutuhan}

Berikut ini disajikan kebutuhan fungsional dan kebutuhan non-fungsional perangkat lunak ini:

Tabel 1. Kebutuhan Fungsional

\begin{tabular}{|c|c|c|}
\hline No & $\begin{array}{l}\text { Kebutuhan } \\
\text { Fungsional }\end{array}$ & Yang dilakukan aktor \\
\hline 1 & $\begin{array}{lr}\text { Sistem } & \text { harus } \\
\text { melakukan } & \text { login } \\
\text { terlebih } & \text { dahulu } \\
\text { sebelum } & \text { dapat } \\
\text { diakses } & \end{array}$ & $\begin{array}{l}\text { Admin dan kasir melakukan login } \\
\text { terlebih dahulu }\end{array}$ \\
\hline 2 & $\begin{array}{l}\text { Sistem harus mampu } \\
\text { mengelola data user }\end{array}$ & $\begin{array}{l}\text { Admin melakukan pengelolaan } \\
\text { data user }\end{array}$ \\
\hline 3 & $\begin{array}{l}\text { Sistem harus mampu } \\
\text { menerima pesanan } \\
\text { banner }\end{array}$ & $\begin{array}{l}\text { Admin dan kasir melakukan input } \\
\text { pesanan banner }\end{array}$ \\
\hline 4 & $\begin{array}{l}\text { Sistem harus mampu } \\
\text { memberikan info } \\
\text { banner yang telah } \\
\text { diambil }\end{array}$ & $\begin{array}{l}\text { Admin dan kasir melakukan input } \\
\text { banner yang diambil }\end{array}$ \\
\hline 5 & $\begin{array}{l}\text { Sistem harus mampu } \\
\text { mengelola laporan } \\
\text { transaksi }\end{array}$ & $\begin{array}{l}\text { Admin dan kasir melakukan } \\
\text { pengelolaan transaksi pembayaran } \\
\text { banner }\end{array}$ \\
\hline 6 & $\begin{array}{lr}\text { Sistem harus } & \text { mampu } \\
\text { backup } & \text { restore } \\
\text { database } & \end{array}$ & $\begin{array}{l}\text { Admin dan kasir melakukan } \\
\text { backup dan restore database }\end{array}$ \\
\hline
\end{tabular}

Tabel 2. Kebutuhan Fungsional

$\begin{array}{lll}\text { No } & \text { Kebutuhan Uraian } \\ & \text { Non- } & \\ & \text { Fungsional }\end{array}$

$1 \quad$ Operasional Sistem Operasi: Windows 7/32 bit; Spesifikasi Komputer: Processor (Pentium 4 / Dualcore 1,6 Ghz), RAM: $512 \mathrm{MB}$, VGA: 256 MB, Monitor: 14' inch, Keyboard: Type USB Cable Standar 101/102 key, Mouse: Type USB Cable with optical; Web Browser: Google Chrome, Internet Explorer \& Mozilla Firefox; Web Server: Apache; Database Server: MySQL; Yii Framework versi 1.1; Sublime Teks 3; XAMPP versi 1.7.3 dengan support PhpMySQL.

2 Keamanan

Sistem aplikasi dan database dilengkapi dengan password;

Johni S Pasaribu 
dilengkapi dengan CCTV.

Digunakan untuk menampilkan
tata cara pemesanan banner;
digunakan untuk menampilkan
informasi bila user salah
memasukkan 4 pasword;
memberikan laporan transaksi

\section{III.2 Analisis dan Disain}

Peneliti menggunakan metode paradigma berorientasi objek dimana semua data dan fungsi dibungkus dalam kelas-kelas atau objek-objek. Berikut ini diberikan diagram usecase dimana akan diketahui siapa aktor (pengguna) yang terlibat dan aktivitas-aktivitas aktor serta interaksi aktor tersebut dengan sistem maupun dengan dunia luar.

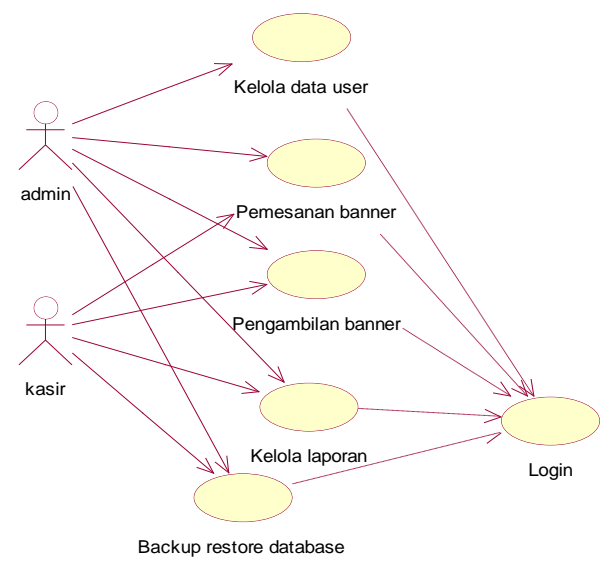

Gambar II. Use Case Diagram

Class Diagram berisikan deskripsi atau penggambaran dari kelas, atribut, dan objek disamping itu terdapat hubungan satu sama lain seperti pewarisan, asosiasi, agregasi dan lainnya. Berikut ini adalah class diagram untuk aplikasi pemesanan banner di Warna Print Kota Cimahi:

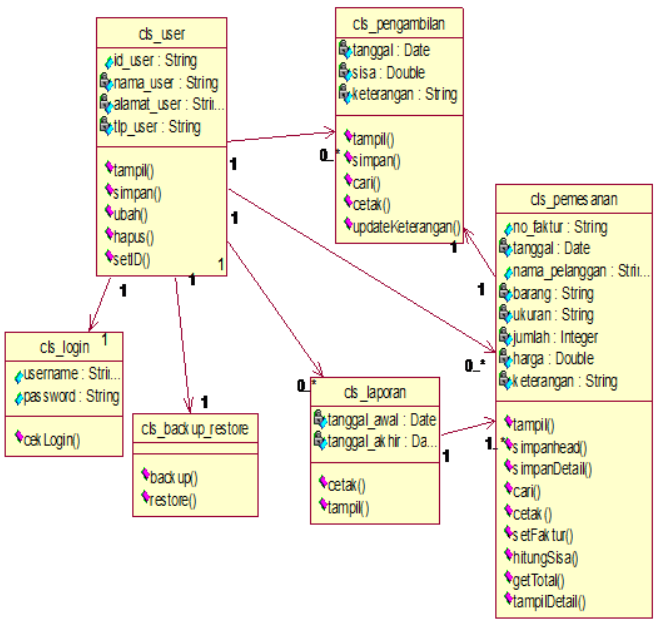

Gambar III. Class Diagram

\section{III.3 Implementasi Antar Muka}

Setelah melalui tahap analisis kebutuhan dan perancangan, maka selanjutnya pada tahap implementasi, dimana disini akan dijelaskan beberapa hasil pembuatan aplikasi pemesanan banner di Warna Print Kota Cimahi. Gambar IV halaman Login berfungsi agar kasir/admin dapat mendaftarkan diri. Adapun uraiannya: buka aplikasi pemesanan banner di Warna Print Kota Cimahi, pilih menu Login, isi semua field yang sudah disediakan. Halaman Login bisa dilihat pada Gambar IV:

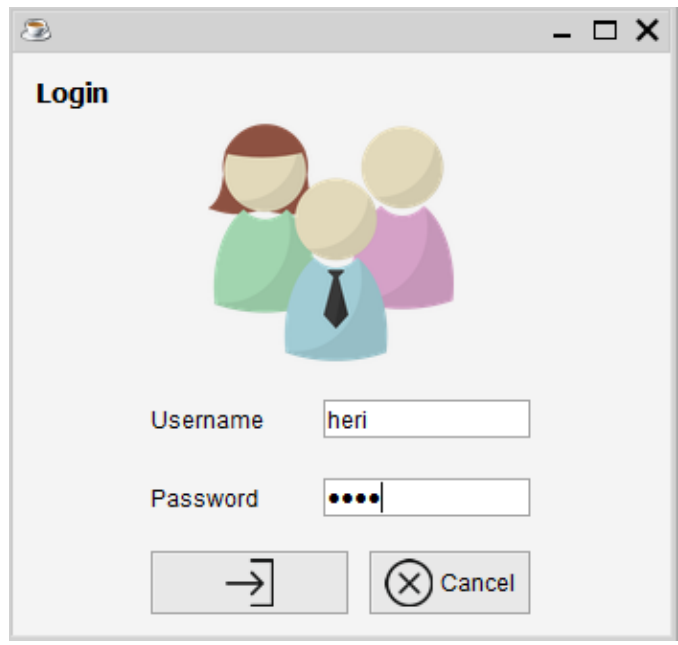

Gambar IV. Login 
Gambar V adalah tampilan Manage User yang berguna untuk mengelola data user. Bila klik tabel yang berisi data pengguna, lalu secara otomatis kolom-kolom data pengguna akan terisi, id user tidak dapat diubah, namun seluruh data lain bisa diisi dengan lengkap.

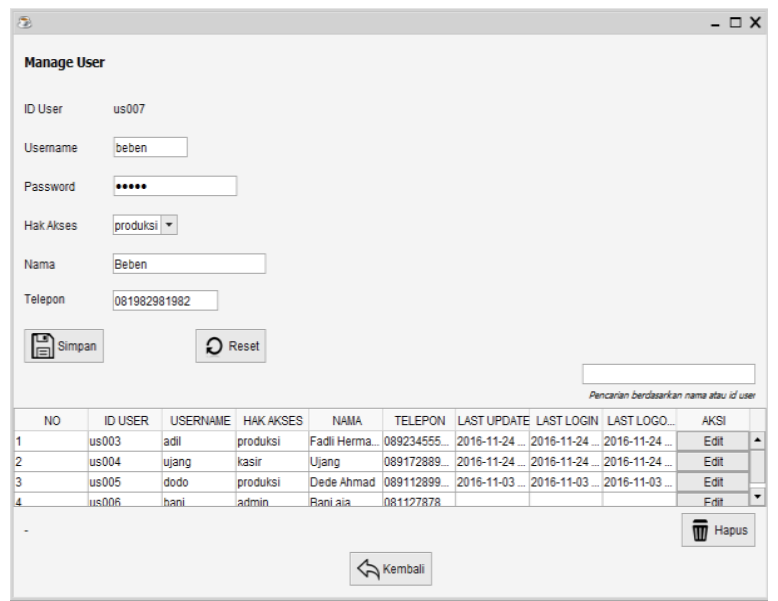

Gambar V. Halaman Manage User

Pada halaman Pemesanan dan Pembayaran berguna untuk untuk menyimpan data pemesanan dan pembayaran. Bila seluruh data telah diisi dengan lengkap, klik tombol hitung untuk menghitung total harga pesanan banner. Kemudian klik tombol simpan untuk menyimpan pemesanan barang, data pemesanan barang akan tampil pada tabel pemesanan barang. Isi kembali data pemesanan jika transaksi pemesanan belum selesai. Isikan jumlah yang akan dibayarkan, dan tunai adalah jumlah yang dibayarkan. Berikut ini ditunjukkan halaman Pemesanan dan Pembayaran:

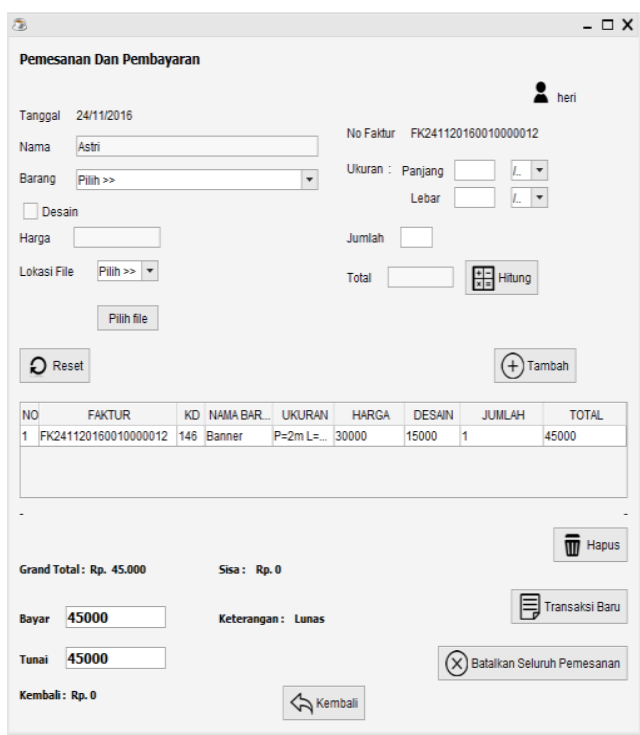

Gambar VI. Halaman Pemesanan dan Pembayaran

Menu Pengambilan dan Pelunasan berguna untuk menyimpan data pengambilan dan pelunasan. Cara penggunaannya yaitu isi kolom pencarian berdasarkan nomor faktur atau nama untuk mencari data pemesanan. Kemudian klik data pemesanan pada tabel, maka kolom faktur, nama dan sisa pembayaran akan terlihat secara otomatis. Kemudian isi kolom pembayaran dengan nominal uang yang dibayarkan, lalu tekan enter untuk menghitung kembalian. Halaman Pengambilan dan Pelunasan bisa dilihat pada gambar VII: 


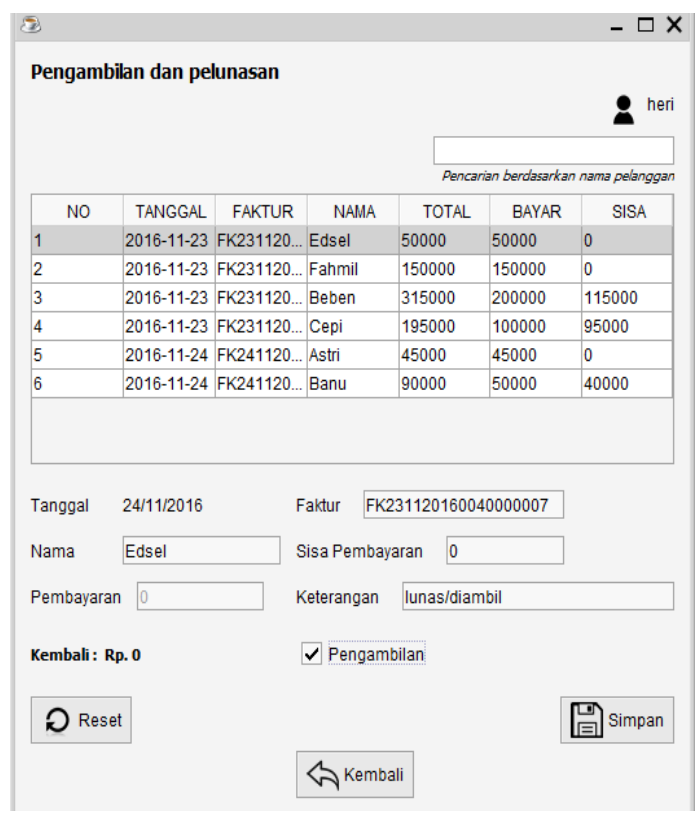

Gambar VII. Halaman Pengambilan dan Pelunasan

Selanjutnya pada tampilan Daftar Pemesanan berguna untuk untuk mencari data pemesanan. Caranya yaitu isi kolom pencarian berdasarkan faktur atau tanggal pemesanan kemudian klik detail untuk melihat detail pemesanan. Menu Daftar Pemesanan dapat dilihat pada Gambar VIII:.

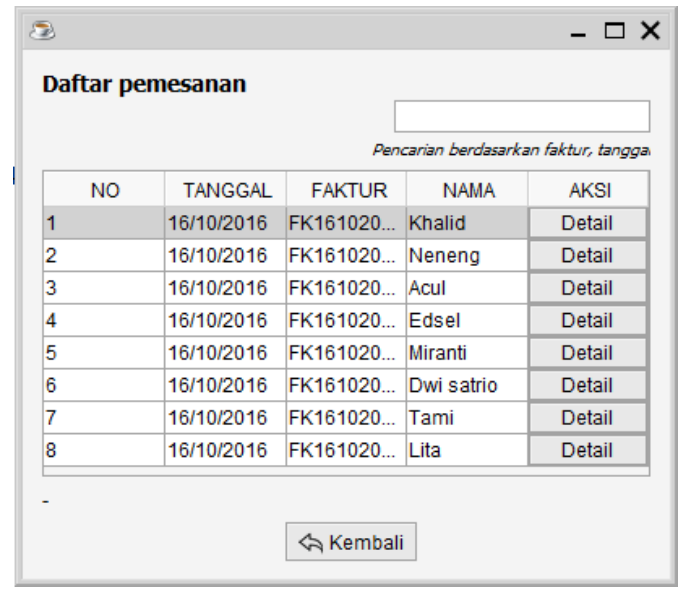

Gambar VIII. Halaman Daftar Pemesanan

Setelah klik Daftar Pemesanan maka akan terlihat Detail Pemesanan berdasarkan nomor faktur pemesanannya seperti terlihat gambar IX.

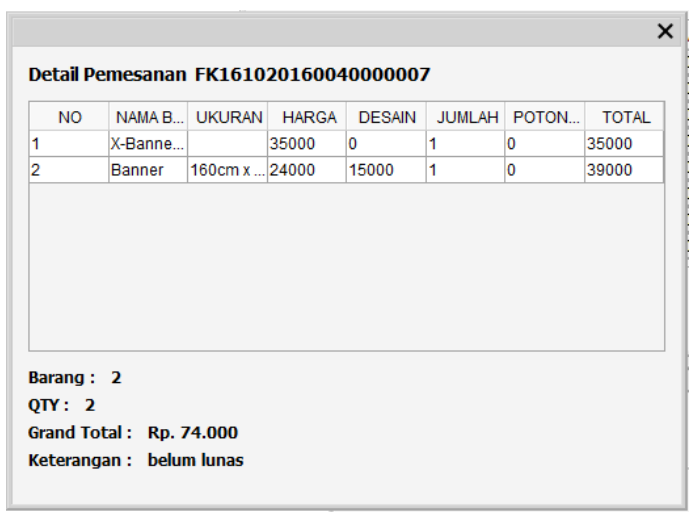

\section{Gambar IX. Halaman Detail Pemesanan}

Selanjutnya pada halaman Daftar Pengambilan berguna untuk untuk mencari data pengambilan. Caranya yaitu isi kolom pencarian berdasarkan faktur atau tanggal pemesanan kemudian klik detail untuk melihat detail pengambilan. Halaman Daftar Pengambilan dapat dilihat pada Gambar X:.

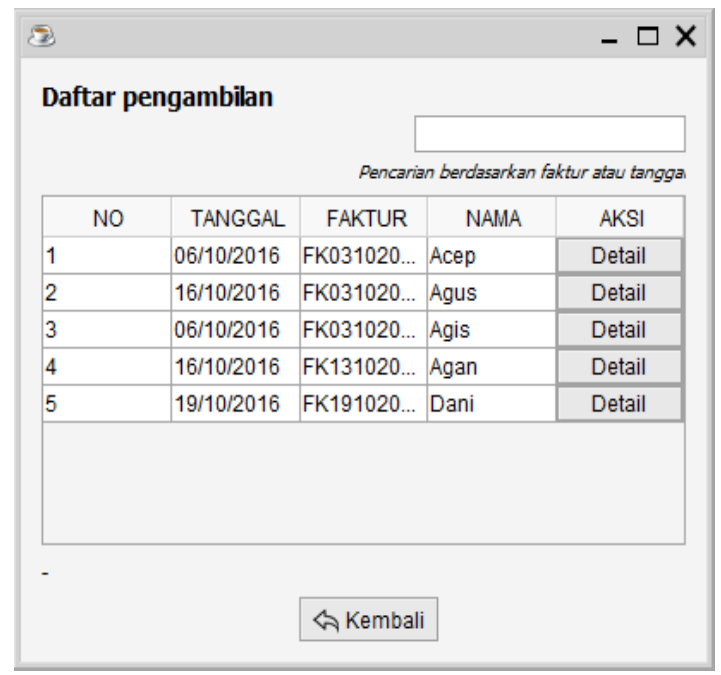

Gambar X. Halaman Daftar Pengambilan

Setelah klik Detail Pengambilan maka akan terlihat isi Detail Pengambilan berdasarkan nomor faktur pemesanannya seperti terlihat gambar XI berikut:

Johni S Pasaribu 


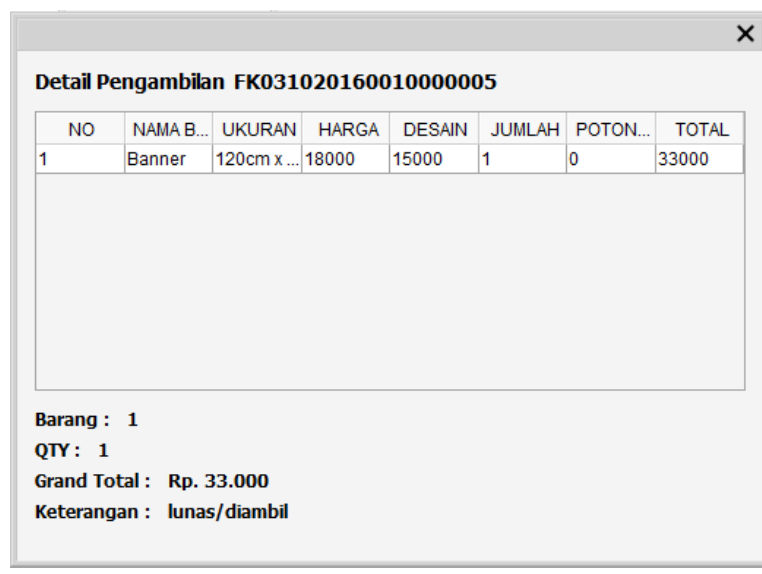

Gambar XI. Halaman Detail Pengambilan

Pada tampilan Backup Restore Database berguna untuk backup dan restore database. Untuk cara penggunaannya Backup yaitu klik tombol Cari untuk mencari lokasi tempat file akan di backup, kemudian klik tombol backup untuk membackup database. Berikut ini ditunjukkan Form Backup Database:

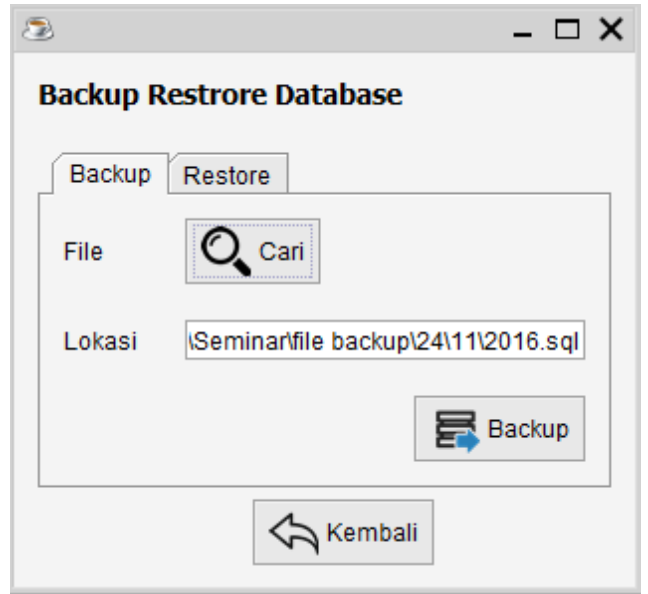

Gambar XII. Halaman Backup Database

Pada tampilan Backup Restore Database selain berguna untuk backup juga untuk restore database. Untuk cara penggunaannya Restore yaitu klik tombol Cari untuk mencari file sql yang akan di restore. Kemudian klik tombol Restore untuk restore database. Berikut ini ditunjukkan Form Restore Database:

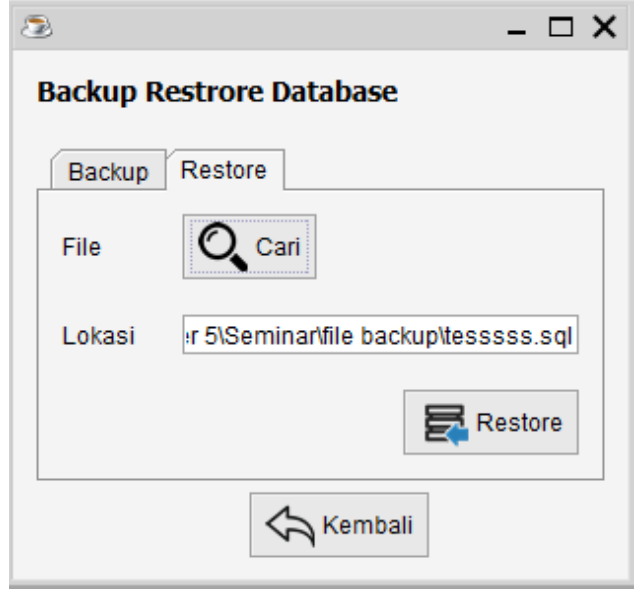

Gambar XIII. Halaman Restore Database

Pada halaman Laporan Transaksi berguna untuk melihat laporan transaksi sesuai tanggal transaksi. Untuk cara penggunaannya yaitu isi parameter tanggal kemudian klik tombol Cari. Berikut ini ditunjukkan Form Laporan Transaksi:

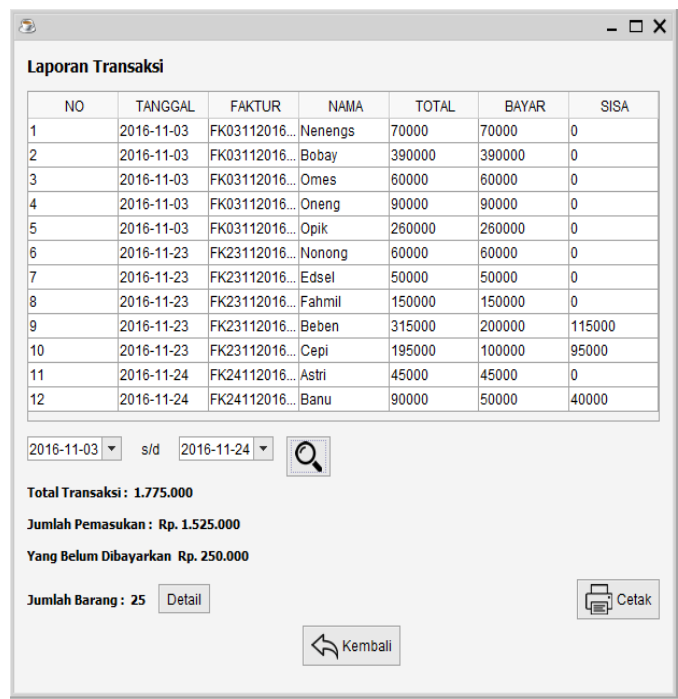

Gambar XIV. Halaman Laporan Transaksi

Setelah klik tombol Detail maka akan terlihat detail jumlah barang transaksi seperti terlihat Gambar $\mathrm{XV}$ : 


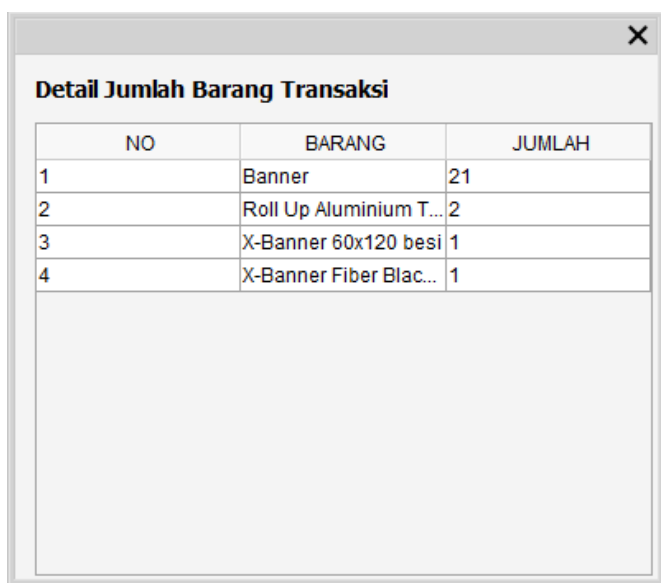

Gambar XV. Halaman Detail Jumlah Barang Transaksi

\section{KESIMPULAN DAN SARAN}

Dari hasil implementasi yang diperoleh dan pembahasan sebelumnya, maka terdapat kesimpulan sebagai berikut:

1. Aplikasi pemesanan banner di Warna Print Kota Cimahi ini merupakan aplikasi yang bermanfaat dalam media informasi sebagai bentuk perkembangan teknologi dan informasi.

2. Aplikasi yang telah dibuat dapat mempercepat pegawai dalam menjalankan tugasnya dalam perihal pencatatan dan pengelolaan data.

3. Aplikasi ini mengoptimalisasi laporan dari setiap proses transaksi yang sudah dilakukan.

Adapun saran-saran yang berkaitan dengan penelitian ini adalah sebagai berikut:

1. Pengembangan selanjutnya diharapkan bisa menggunakan sms gateway.

2. Pengembangan selanjutnya dapat mengasilkan laporan dengan berbentuk grafik.

\section{REFERENSI}

Aditya, A. N. (2011). Jago PHP dan MySQL. Dunia Komputer.

Ahyari, A. (1999). Manajemen Produksi
Perencanaan Sistem Produksi (4th ed.). BPFE.

Chris, E. and. (1999). Marketing Communication, Contexts, Contents and Strategies. Prentice Hall.

Dhanta. (2009). Aplikasi Web. Elex Media Komputindo.

Juansyah, A. (2015). Pembangunan Aplikasi Child Tracker Berbasis Assisted- Global Positioning System (A-GPS) Dengan Platform Android [Universitas Komputer Indonesia]. https://textid.123dok.com/document/7qv8e7dzpembangunan-aplikasi-child-tracker-berbasisassisted-global-positioning-system-a-gpsdengan-platform-android.html

Kadir, A. (2003). Pengenalan Sistem Informasi. Andi.

Kadir, A. (2008). Tuntunan Praktis Belajar Database Menggunakan MySQL. Andi.

Munnasar, N.M.A and Govardhan, A. (2010). A Comparison Between Five Models Of Software Engineering. IJCSI International Journal of Computer Science, vol 7, no, 95-97. https://www.ijcsi.org/papers/7-5-94-101.pdf

Nugroho, A. (2005). Analisis dan Perancangan Sistem Informasi Dengan Metodologi Berbasis Objek. Informatika.

Pressman, R. S. (2012). Rekayasa Perangkat Lunak (Pendekatan Praktisi) Buku 1 (7th ed.). Andi Offset.

Riyanto. (2010). Membuat Sistem Informasi Penjualan dengan PHP dan MySQL. Gava Media.

Saydam, G. (1996). Manajemen Sumber Daya Manusia: Suatu Pendekatan Mikro. Djambatan.

Shalahuddin, M \& Rossa, A. S. (2013). Rekayasa Perangkat Lunak Terstruktur dan Berorientasi Objek. Informatika.

Sugiyono. (2014). Metode Penelitian Kuantitatif, Kualitatif, dan R\&D. CV. Alfabeta. 